\title{
Computer modeling applications in Engineering Graphics lessons
}

\author{
Smirnova, Z.V. ${ }^{1}$ Vaganova O.I. $^{2}$, Bystrova, N.V. ${ }^{3}$, Kaznacheeva S.N. ${ }^{4}$, Krylova T.V. ${ }^{5}$ \\ ${ }^{1}$ Minin Nizhny Novgorod State Pedagogical University (Minin University), Nizhny Novgorod, Russian Federation \\ z.v.smirnova@mininuniver.ru \\ ${ }^{2}$ Minin Nizhny Novgorod State Pedagogical University (Minin University), Nizhny Novgorod, Russian Federation \\ vaganova_o@mail.ru \\ ${ }^{3}$ Minin Nizhny Novgorod State Pedagogical University (Minin University), Nizhny Novgorod, Russian Federation \\ bystrova_nv@mail.ru \\ ${ }^{4}$ Minin Nizhny Novgorod State Pedagogical University (Minin University), Nizhny Novgorod, Russian Federation \\ cnkaznacheeva@gmail.com \\ ${ }^{5}$ Minin Nizhny Novgorod State Pedagogical University (Minin University), Nizhny Novgorod, Russian Federation \\ perova_ta@mininuniver.ru
}

\begin{abstract}
The use of computer modeling in technical lessons is one of the innovative technologies of the educational process in universities. In modern education today, one of the necessary conditions for the formation of personality is an educational environment capable of providing an opportunity for the development of abilities. The use of computers in the lesson in engineering graphics has long been in the center of attention of university teachers. Students with great pleasure work on the computer, performing complex tasks. Modern electronic computers allow us to move from traditional, manual methods for developing design documentation to new information technologies using specialized software. At the same time, the received documentation fully complies with the ESKD standards for the quality of execution of documents.

The purpose of the article is to form students' professional competencies in the process of applying computer modeling in the Engineering Graphics lesson. In this regard, the relevance of our study lies in the search for effective ways of organizing the educational process using computer technology in the field of graphics and graphic information. The study showed that the use of computer modeling in technical lessons increases the level of knowledge, skills and abilities. Improves the quality of assimilation of the material.
\end{abstract}

Key words:Computer modeling, engineering graphics, information technology, professional competencies, educational results.

\section{INTRODUCTION}

In modern education today, one of the necessary conditions for the formation of personality is an educational environment capable of providing an opportunity for the development of abilities. Among such abilities, it is necessary to note the technical development, perception and processing of graphic information. Today, widely used means of visual display of graphic information, which is used in all areas of society.
Today, many enterprises are undergoing restructuring of design and development activities using information technologies; such technologies require training of specialists in educational institutions who own computer graphics and computer-aided design of parts and products [1].

Students of educational institutions should have a complete picture of the possibilities of using computer graphics in various spheres of life. In its structure, engineering graphics is the most complex and timeconsuming material in the assimilation of information.

The use of computers in the lesson in engineering graphics has long been in the center of attention of university teachers. Students with great pleasure work on the computer, performing complex tasks.

In this regard, the relevance of our study lies in the search for effective ways of organizing the educational process using computer technology in the field of graphics and graphic information.

Many universities are developing programs and methodological developments for teaching computer graphics, but still there is not enough experience in organizing the educational process using a computer.

In modern education today, one of the necessary conditions for the formation of personality is an educational environment capable of providing an opportunity for the development of abilities. Among such abilities, it is necessary to note the technical development, perception and processing of graphic information. Today, widely used means of visual display of graphic information, which is used in all areas of society [2].

Today, many enterprises are undergoing restructuring of design and development activities using information technologies; such technologies require training of specialists in educational institutions who own computer graphics and computer-aided design of parts and products. Students of educational institutions should have a complete picture of the possibilities of using computer graphics in various spheres of life. In its structure, engineering graphics is the most complex and timeconsuming material in the assimilation of information. 
The use of computers in the lesson in engineering graphics has long been in the center of attention of university teachers. Students with great pleasure work on the computer, performing complex tasks [3].

In this regard, the relevance of our study lies in the search for effective ways of organizing the educational process using computer technology in the field of graphics and graphic information.

Many universities are developing programs and methodological developments for teaching computer graphics, but still there is not enough experience in organizing the educational process using a computer.

The problem of using computer modeling in teaching a discipline has been studied for a long time. Currently, the use of computers in educational activities occupies a major position. Modern requirements for the provision of spatial imagination update the knowledge of information programs for their implementation. In the studies of Smirnova Zh.V., Markova S.M., Vaganova O.I. and others emphasizes the relevance of this study - the use of information technology in educational activities. Research in the field of computer technology increases the level of development of spatial imagination for certain labor activities.

Training in computer modeling was provided for in the subject of computer science at the initial stage of its introduction into school (A.G. Gein, V.G. Zhitomirsky, E.V. Linetsky, etc.). N.V. Makarova and Yu.F. Titova developed a methodology for teaching modeling and clarified the content of training for this section, namely: a diagram of the stages of modeling, definition of a modeling object, consideration of the concepts of an object, model, system, etc.

Yu.F. Titova developed a methodology for teaching twodimensional computer graphics for students in the lessons of Graphics. The development of elective courses in computer modeling and computer graphics was done by JI.A. Zalogova, M.Yu. Monks, C.JI. Solodov, G.E. Monakhova, A.B. Kopyltsov, I.G. Semakin, E.K. Henner. The construction of the methodological training system for vector graphics and its implementation in the form of a special training course at the stage of specialized training was performed by O.Yu. Ilyashenko. V.V. Aleksandrova developed a methodology for teaching three-dimensional modeling using a finite set of basic forms for conditions of additional education.

In the study, E.Yu. Tikhomirova revealed the conditions for using computer support for the study of geometric material for the development of generalized spatial representations of students. In this study, a technique was developed that includes the stage of three-dimensional computer modeling when teaching geometric material in universities in the subject of Engineering Graphics.

There are practically no studies directly devoted to the development of the content of training in computer modeling in the course Engineering Graphics for students at a university. In this regard, the problem of teaching computer modeling at a university on a course in Engineering Graphics is relevant.

\section{METHODOLOGY}

After analyzing the methodological literature, and also relying on personal experience, we can determine the subject of pedagogical technology - these are concrete practical interactions of teachers and students organized on the basis of clear structure in any field of activity, systematization, programming, algorithmization, standardization of methods and techniques of teaching and upbringing. As a result, the result is achieved in the students' successful mastery of knowledge, skills, and the conditions are created for the formation of valuable social norms and behavior habits. [4].

The use of computer technology has become one of the tasks of educational institutions to train specialists in engineering specialties. In 2019, we conducted studies on the effectiveness of computer modeling in the process of students studying the discipline of Engineering Graphics. The study involved 2 first-year groups of 20 people (control and experimental), both groups studied this discipline in the same volume by the number of hours. During the study, we set the criteria for the introduction of differentiated learning:

- quality of work performed;

- how much time to complete the task;

- independence in the analysis of the task.

Students' completed work was evaluated according to the levels of mastering the material and completing assignments. Professional competencies table 1.

The study was supervised by a teacher. After the work is completed, indicators are processed based on the result of the study [5].

\section{RESULT AND DISCUSSION}

In the process of studying the use of computer modeling in Engineering Graphics lessons, 1st year students took part in the areas of preparation "Technology and Economics" and "Computer Science and Technology". The study was conducted over one semester [6].

The level of students' training on the use of computer modeling in the lessons Engineering graphics was assessed by the formation of professional competencies of the main educational program Table 1 .

The course "Engineering Graphics", as well as other module disciplines, is aimed at creating professional readiness for the implementation of labor activities established by the Professional standard of a teacher and universal, general professional, professional competencies of the Federal State Educational Standard of Higher Education in the field of training "Pedagogical Education". [7].

As a result of mastering the discipline, the student should have a number of "input" knowledge, skills and possessions, in particular: be able to apply theoretical knowledge for practical purposes, correctly set and solve organizational problems in the field of teacher education, and use innovative technologies [8].

The discipline "Graphics" is logically connected with the disciplines of the module. The development of this discipline is the basis for the subsequent study of the disciplines of the modules of subject preparation and training.

The purpose of the discipline is the formation of systematic knowledge and competencies in the field of graphic disciplines for the development of polytechnic training of students. 
Objectives of the discipline:

- the formation of basic knowledge and skills used in the field of graphic disciplines;

- systematization of modern knowledge of graphic disciplines [9].

Table 1: Educational Results Source (own authorship).

\begin{tabular}{|c|c|c|c|}
\hline $\begin{array}{c}\text { Module } \\
\text { OP } \\
\text { code } \\
\end{array}$ & $\begin{array}{l}\text { Educationalmo } \\
\text { duleresults }\end{array}$ & $\begin{array}{l}\text { EducationalDis } \\
\text { ciplineResults }\end{array}$ & $\begin{array}{c}\text { Evaluation } \\
\text { Tools }\end{array}$ \\
\hline OP.1 & $\begin{array}{l}\text { Able to search, } \\
\text { critical analysis } \\
\text { and synthesis } \\
\text { of information, } \\
\text { apply a } \\
\text { systematic } \\
\text { approach to } \\
\text { solving the } \\
\text { tasks within the } \\
\text { scientific } \\
\text { worldview }\end{array}$ & $\begin{array}{l}\text { He knows the } \\
\text { basic concepts, } \\
\text { the role and } \\
\text { significance of } \\
\text { descriptive } \\
\text { geometry and } \\
\text { drawing; } \\
\text {-state } \\
\text { standards; } \\
\text {-informational } \\
\text { capabilities of } \\
\text { the drawings. } \\
\text { Able to select } \\
\text { the necessary } \\
\text { scientific and } \\
\text { reference } \\
\text { literature and } \\
\text { use it in } \\
\text { educational } \\
\text { activities. }\end{array}$ & $\begin{array}{l}\text { Test } \\
\text { Test } \\
\text { Settlement } \\
\text { and graphic } \\
\text { Practical } \\
\text { task }\end{array}$ \\
\hline OP. 2 & $\begin{array}{l}\text { Demonstrates } \\
\text { the ability to } \\
\text { apply subject } \\
\text { knowledge in } \\
\text { the } \\
\text { implementation } \\
\text { of the } \\
\text { educational } \\
\text { process based } \\
\text { on scientific } \\
\text { knowledge and } \\
\text { current trends } \\
\text { in the } \\
\text { development of } \\
\text { engineering and } \\
\text { technology }\end{array}$ & $\begin{array}{l}\text { Able to apply } \\
\text { methods of } \\
\text { transforming } \\
\text { the drawing, } \\
\text { solve metric } \\
\text { and positional } \\
\text { tasks, perform } \\
\text { sweeps of } \\
\text { bodies. } \\
\text { He knows the } \\
\text { methods and } \\
\text { methods of } \\
\text { descriptive } \\
\text { geometry; } \\
\text { methods for } \\
\text { constructing } \\
\text { sketches, } \\
\text { working and } \\
\text { assembly } \\
\text { drawings, } \\
\text { technical } \\
\text { drawings of } \\
\text { parts. }\end{array}$ & $\begin{array}{l}\text { Test } \\
\text { Test } \\
\text { Settlement } \\
\text { and graphic } \\
\text { Practical } \\
\text { task }\end{array}$ \\
\hline OP 3 & $\begin{array}{l}\text { Demonstrates } \\
\text { readiness to use } \\
\text { systematic } \\
\text { theoretical and } \\
\text { practical } \\
\text { knowledge for } \\
\text { the formulation } \\
\text { and solution of } \\
\text { design and } \\
\text { research } \\
\text { problems }\end{array}$ & $\begin{array}{l}\text { Able to find } \\
\text { optimal } \\
\text { solutions to } \\
\text { problems and } \\
\text { use them in } \\
\text { professional } \\
\text { activities; } \\
\text { He has the } \\
\text { skills of } \\
\text { practical } \\
\text { judgment and } \\
\text { assessment of } \\
\text { the significance } \\
\text { of the studied } \\
\text { material. }\end{array}$ & $\begin{array}{l}\text { Test } \\
\text { Test } \\
\text { Settlement } \\
\text { and graphic } \\
\text { Practical } \\
\text { task }\end{array}$ \\
\hline
\end{tabular}

Based on the results of the study, assessment activities were carried out in 2 groups: settlement and graphic works, practical tasks, testing and tests. The tasks in the groups were the same, but they were carried out using different technologies. The experimental group performed assessment tasks using computer technology. Students worked in AutoCAD 2019 programs [10]. The program allows you to:

- Intelligent dimensioning. The length of the object is highlighted when you hover over it. Thanks to this, you can make adjustments to the finish [11].

- Viewports. By interacting with large models, you can bring to the forefront individual areas of the drawing.

- Marked clouds. They allow you to highlight changed areas, which makes working with comments in AutoCAD quick and accurate.

- Linking information. There is no need to separately make adjustments to adjacent tables. During integration, the data will be pulled automatically [12].

- Export from Microsoft Excel. Now you can use formulas for calculations, the data from which can be summarized in the specification. [13].

The control group performed tasks on the usual technologies of teaching Engineering Graphics. The result of the study showed the following data in Figure. 1.

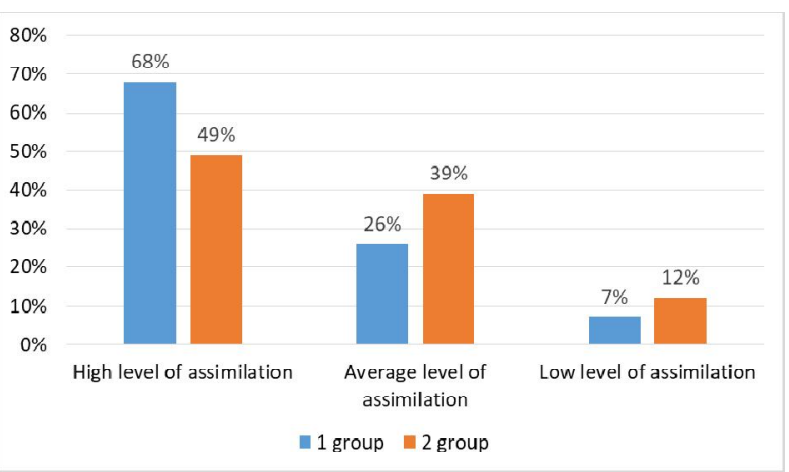

Figure 1: Level of Competency Source (own authorship).

We see that the level of development of professional competencies, knowledge of skills in the experimental group is higher than in the control group, $67 \%$ received an average educational result, $26 \%$ average result, $7 \%$ low indicator. In the control group, the result of mastering the educational program in the discipline Engineering Graphics is much lower: a high level of $49 \%$, an average level of mastery of the material $39 \%$, a low level of $12 \%$. [14].

\section{CONCLUSION}

The article studies the use of computer modeling in the discipline of Engineering Graphics. [15,16].The use of computer programs for the formation of professional competencies of specialists in need in the engineering field, allows increasing the formation of professional competencies, to expand technical knowledge on the design and modeling of objects. [16].The results of training in the experimental group confirmed the quality of knowledge formation using computer technology. About research results, $67 \%$ received a high result in the quality of training. The formation of professional competencies using computer technologies in the educational process becomes more effective in the study of a specific discipline of Engineering Graphics 


\section{REFERENCES}

1. Gruzdeva M.L., Smirnova Z.V., Chaikina Z.V., Golubeva O.V., Cherney O.T. (2019a) methodology Lecture Notes in Networks and Systems T. 57. s. 11931199 .

2. Gruzdeva, M.L., Smirnova, Z.V., Chaikina, Z.V., Golubeva, O.V., Cherney, O.T. (2019b) Using internet services in teaching methodology Lecture Notes in Networks and Systems, 57, pp. 1193-1199.

3. Kostylev D.S., Kostyleva, E.A., Perevozchikova, N.G., Sirotyk, S.D, Lazutina, A.L., Vaganova, O.I., Smirnova, Z.V. (2019) Development of a model for assessing the activities of teachers in an educational organization International Journal of Innovative Technology and Exploring Engineering 8(9), c. 2328-2332

4. Levkova A.A., Smirnova Zh.V. (2020) Non-traditional forms of training in the field of computer science using new technologies//Innovative economy: prospects for development and improvement. No. 1 (43). S. 209-216.

5. Markova S.M. (2013a) Professional values in the conditions of continuous multilevel education // VestnikMininskogouniversiteta (Vestnik of Minin University), No. 3 (3). S.10.

6. Markova, S.M., Sedykh, E.P., Polunin, V.Y., Tsyplakova, S.A. (2020b) Modeling of Integrated Content of Professional Education for Future Workers and Specialists Lecture Notes in Networks and Systems 73, c. 1087-1095

7. Smirnova Z.V., Kuznetsova E.A., Koldina M.I., Dyudyakova S.V., Smirnov A.B. (2020a) Organization of an inclusive educational environment in a professional educational institution// Collected: Lecture Notes in Networks and Systems. Growth Poles of the Global Economy: Emergence, Changes and Future Perspectives. Plekhanov Russian University of Economics. Luxembourg,.S. 1065-1072.

https://doi.org/10.1007/978-3-030-15160-7_107

8. Smirnova Z.V., Vaganova O.I., Chanchina A.V., Koldina M.I., Kutepov M.M.(2020b) Development of research activity of future economists in the university In the collection: Lecture Notes in Networks and Systems. Growth Poles of the Global Economy: Emergence, Changes and Future Perspectives. Plekhanov Russian University of Economics. Luxembourg,.S. 371-379.

9. Smirnova Z.V., Vaganova O.I., Gruzdeva M.L., Golubeva O.V., Kutepov M.M. (2020c) Social and economic efficiency and quality of providing services to the population in the form of service activities In the collection: Lecture Notes in Networks and Systems. Growth Poles of the Global Economy: Emergence, Changes and Future Perspectives. Plekhanov Russian University of Economics. Luxembourg, S. 1029-1039.

10. Smirnova Z.V., Vaganova O.I., Loshkareva D.A., Konyaeva E.A., Gladkova M.N. (2019d) Practice-oriented approach implementation in vocational education In the collection: IOP Conference Series: Materials Science and Engineering. S. 012003.

https://doi.org/10.1088/1757-899X/483/1/012003

11.Smirnova Z.V., Vaganova O.I., Vinnikova I.S., Lapshova A.V., Golubeva O.V.(2020e) Modern multimedia didactic tools of interactive training //
Collected: Lecture Notes in Networks and Systems. Growth Poles of the Global Economy: Emergence, Changes and Future Perspectives. Plekhanov Russian University of Economics. Luxembourg, S. 485-491.

12. Smirnova Zh.V., Kochnova K.A. (2019k) Training of employees of service enterprises using information technologies Vestnik of Minin University. Vol. 7. No. 1 (26). S. 5.

13.

14. Smirnova Zh.V., Vaganova O.I. (20191) Handmarking at higher education institution through electroniceducational environment //Innovative economy: prospects for development and improvement..No3 (37). S. 111-118.

15. Smirnova, Z.V., Kamenez, N.V., Vaganova, O.I., Kutepova, L.I., Vezetiu E.V. (2019n). The experience of using the webinar in the preparation of engineering specialists. Amazonia Investiga, 8 (18), 279-287.

16. Smirnova, Zh. V., Krasikova, O.G. (2018p). Modern tools and technologies for assessing learning outcomes. VestnikMininskogouniversiteta (Vestnik of Minin University), 6 (3), (in Russ.). DOI: 10.26795/2307-12812018-6-3-9.

17. Y. Pratapa Reddy, Dr. K. L Narayana, Dr. M. Kedar Mallik. Electro-chemical behavior of different metals in Sodium Chloride solution. // International Journal of Emerging Trends in Engineering Research, 7 (11), November 2019, 71 Volume 7, No. November 11, 2019.

18. EkoJulianto, WaluyoAdiSiswanto, Marwan Effendy Characteristics of Temperature changes and Stress of Float Glass under Heat Radiation // International Journal of Emerging Trends in Engineering Research, Volume 7, No. September 9, 2019. 